\title{
On Counteracting the Investigation of Prison-Related Crimes: Features of the Preliminary Stage
}

\author{
ALEKSANDR V. AKCHURIN \\ Academy of the Federal Penitentiary Service of Russia, Ryazan, Russian \\ Federation \\ ORCID: https://orcid.org/0000-0003-1742-1162, e-mail: 79206310258@yandex.ru
}

\begin{abstract}
Introduction: the article analyzes the content and typical methods and ways that convicts, suspects, and defendants held in correctional institutions and pre-trial detention centers use to counter the investigation of penitentiary crimes. Aim: using the analysis of investigative and judicial practice for criminal cases initiated against persons who committed crimes while in custody or while serving their prison terms, we make an attempt to identify the most distinctive features of counteracting the investigation of prisonrelated crimes. Methods: dialectical method of cognition, general scientific methods of analysis and generalization, empirical methods of description, interpretation; theoretical methods of formal and dialectical logic. Results: using a scientific approach that highlights the preliminary stage of investigation of crimes, we reveal some typical counteraction techniques used by prison offenders. Conclusions: destruction, concealment, staging, and falsification are among the most popular methods used directly by offenders to prevent prison-related crimes from being solved. The indirect attitude of offenders toward counteracting the investigation of prison-related crimes is successfully implemented by creating a crowd effect, as well as using the media and the activities of human rights organizations.

Key w ords: prison-related crime; counteracting crime investigation; correctional institution; pre-trial detention center; convicted person; suspect; defendant.

12.00.12 - Criminalistics; law enforcement intelligence-gathering activities; forensic expert activities.

For c it ation: Akchurin A.V. On counteracting the investigation of prison-related crimes: features of the preliminary stage. Penitentiary Science, 2021, vol. 15, no. 2 (54), pp. 413-417. DOI 10.46741/2686-9764-2021-15-2-413-417.
\end{abstract}

\section{Introduction}

Persons committing prison offences have always sought to counteract the investigation of crimes. The very essence of the unofficial norms of prison subculture, which the majority of prison offenders adhere to, is reduced to opposing official behavior standards in correctional facilities and pre-trial detention centers. In this regard, V.A. Ishchenko quite accurately draws parallels between the official activities of preliminary investigation bodies and the accompanying activities of criminals to counteract this process [3, pp. 48-56].

The process of neutralizing the counteraction provided during the investigation of prison offences is complicated by the fact that in the prison environment, experience in countering law enforcement agencies is constantly accu- mulated, analyzed and improved. B.A. Polikarpov very aptly noted that the first "lessons" on countering the investigation process are received by prison offenders from their cellmates in pre-trial detention centers [9, p. 22].

\section{Preliminary stage of our investigation}

According to the analysis of criminalistics literature and investigative and judicial practice we can say that opposing the investigation of prison-related crimes is usually not limited to any particular stage of preliminary investigation process, but is often found in the course of judicial proceedings as well. However, within the framework of one article, it is impossible to consider in detail all the features of opposing the investigation of prison-related crimes at all stages. Therefore, we shall limit ourselves to the preliminary stage of investigation, which, as 
a rule, is most closely related to the work of the administration of a correctional facility (pre-trial detention center) that exercises its few criminal procedural powers [10].

Taking the viewpoint of N.G. Shurukhnov [11, p. 152] concerning the preliminary stage, we note that in our opinion this stage should be considered not just as a verification of a report about an upcoming or committed crime, but as a stage of the investigation process. In this case, its content is filled not only with activities aimed at conducting verification work in order to establish elements of the crime or their absence, but also with activities to accumulate a certain amount of evidentiary information obtained as a result of relevant investigative actions.

Ways and techniques of opposing the investigation of prison-related crimes

The analysis of scientific literature and investigative and judicial practice allowed us to identify the following typical ways and techniques of opposing the investigation of prison-related crimes that arise at the preliminary stage.

The most common method is destruction, the essence of which is to eliminate material traces of the crime committed. The analysis of criminal cases on prison offences has shown that material objects that can later act as material evidence are destroyed. More than $62 \%$ of crimes are crimes of violence (Articles 105, 110, $111,112,115,318,321$ of the RF Criminal Code); resulting in numerous human footprints, traces, items, substances, etc. being left at the crime scene.

The following case from the practice of correctional institutions provides a telling example in this regard. The convict P., while serving his prison term, murdered the convict J. on the basis of personal enmity toward him. The crime took place in a workroom of the correctional institution. First, he struck J. at least ten blows onthe neck and torso with a shank. Then he took a hammer that was lying on the floor and, squeezing J.'s neck with one hand, struck him at least 20 blows on the headwith the other hand, which was holding the hammer, thereby inflicting severe bodily injuries in the form of wounds of the face with damage to facial bones, indentation of facial bones in the cerebral cranium, damage to the membranes and substances of the brain, and a blunt neck injury. J. died from the injuries sustained.

Taking advantage of the absence of witnesses, P. took action to destroy the traces of blood left on the floor. He washed himself and changed his clothes. He tried to burn the clothes with traces of blood on them and the murder weapon in the furnace of the forge at the correctional facility (Criminal case No. 1-28/2015. Archive of Ust-Labinsky District Court of Krasnodar Krai).

We interviewed investigators from the RF Investigative Committee, and they indicated that in their investigative practice they encountered the destruction of the following material traces of a crime by convicts (suspects, defendants):

- human traces (traces of hands, feet, teeth, etc.) - $16.9 \%$;

- traces of substances (traces of blood, etc.) $-74.3 \%$;

- traces of objects (objects adapted for inflicting piercing and cutting injuries, objects using a shock-crushing effect, etc.) - 87.9\%;

- other traces $-5.3 \%$.

Staging is another typical way to counteract the investigation of prison-related crimes. The offender, being aware of the inevitability of negative consequences such as the corpse of the victim, wounds, or the occurrence of other events of the crime, seeks to change the environment in which the crime was committed, so that the consequences could be presented in the most plausible way as a result of an accident, natural event, or the victim's suicide. Staging is used quite commonly in prison offences. A survey of employees of correctional institutions and pre-trial detention centers showed that convicts (suspects, defendants) tend to stage a suicide of the victim in $48.4 \%$ of cases and an accident or the victim's natural death in $35.7 \%$.

The following case from the practice of pretrial detention centers is typical. On February 3 , 2011 , at about 19:25, the body of the defendant $\mathrm{K}$. was found in the cell of the psychiatric department of a pre-trial detention center. Previously, during the inspection of the crime scene, signs of suicide by hanging were identified. However, according to the act of forensic medical examination of K.'s corpse, the death of the latter was caused by asphyxia as a result of a closed blunt neck injury, presumably inflicted by another person (Criminal case No. 290535, initiated on March 15, 2011 by the Investigation Department for Kalininsky District of Saint Petersburg under the Main Investigative Department of the Russian IC for Saint Petersburg).

The next way to counteract the investigation of prison-related crimes is concealment. According to M.G. Bushinskaya [1, p. 61], concealment can be implemented in both active and passive forms. 
The active form of concealment is usually associated with the refusal of the perpetrators and witnesses to give explanations or testimony about what happened. The authors who have studied the problems of investigation of prison offences note the so-called "passive" opposition of convicts (suspects, defendants), which, due to the prevalence and persistence of informal communication among convicts, is typical of the majority of persons held in institutions that provide isolation from society $[6,12]$.

Falsification as a way to counteract the investigation of a crime is quite successfully used by prison offenders. In $93.6 \%$ of cases, the method of falsification is implemented by spreading deliberately false information.

Thus, the results of interviewing employees of pre-trial detention centers who studied at the Academy of the Federal Penitentiary Service of Russia on advanced training courses in 2017-2018 showed the prevalence of such a technique as discrediting an employee of the penal system. A convicted person (suspect, defendant) who is interested in the outcome of resolving an illegal event that has become known to a certain employee of a correctional institution (pre-trial detention center) takes action to neutralize the offensive nature of the pre-investigation check. To do this, the convicted person (suspect, defendant) finds out the mobile phone number of this employee and whether there is a bank card account linked to this number. Then the convict transfers money (20-50 thousand rubles) to this account and simultaneously sends a complaint to the Prosecutor's office (or to other human rights organization). The complaint contains false information that an employee of a correctional institution (pre-trial detention center) has allegedly extorted money from the convict (suspect, defendant) under the pretext of resolving the issue of termination of criminal prosecution. The consequence of this is that numerous verification measures are carried out by the internal security units in relation to this employee of a correctional institution (pre-trial detention center); such a situation significantly complicates the work of the employee who is forced to give explanations instead of fully performing their professional duties.

The practice of such falsifications shows that even if an employee of a correctional institution (pre-trial detention center), having promptly identified an unjustified replenishment of their own account, turns to their own security unit or to their senior, it does not save the employee from inspection activities related to the mes- sage received. And in the context of a largescale fight against corruption, these verification measures are carried out quite thoroughly. At the same time, in personal conversation, the employees of correctional facilities (pre-trial detention centers) who turned out in such a situation note that in addition to a colossal waste of time such checks (even if the outcome for the employee is positive) undermine the employee's positive attitude toward further proactive work to maintain law and order in the correctional facility (pre-trial detention center).

In the conditions of correctional institutions and pre-trial detention centers, an especially favorite technique for countering the investigation of prison-related crimes is to create a crowd effect. V.V. Nikolaychenko calls this technique "igniting" the crowd. Its essence lies in the fact that persons who, as a rule, have the status of leaders of negative orientation groups use the mental state of other convicts (suspects, defendants) and resort to psychological infection spread by ear-shredding screams, heart-rending moans, calls for help and disobedience to employees of the administration of a correctional institution (pre-trial detention center). In the conditions of an "infected" crowd, its individual participants "lose their sense of personal responsibility for their actions, and their level of consciousness and criticality toward the situation decreases. They are ready for anything, they are fanatics. Under the circumstances, they can shout any inflammatory slogan, any threat" [7, pp. 350-356].

We should focus separately on a counteraction method such as the use of mass media and human rights organizations as a kind of tool of public pressure on the administration of a correctional institution (pre-trial detention center), investigation and inquiry bodies.

The democratic processes that became much more intense in our country in the early 1990s gradually made the penitentiary system and everything that happens in it more open and accessible to civil society. It is obvious that such processes play a positive role, first of all in ensuring and protecting the rights and freedoms of convicts held in such institutions.

Non-governmental organizations, human rights organizations, and mass media take advantage of such an accessibility of correctional institutions and often cover the work of correctional facilities very actively or build their own work in close contact with correctional institutions.

Unfortunately, such kind of interest on the part of non-governmental, human rights or- 
ganizations and the media is not often implemented as a constructive dialogue with prison administration or addresses pressing life issues and improvement of the process of reformation of convicts. Quite often, such interest in correctional institutions is caused by a simple need to obtain scandalous news that allows the media to raise their own ratings, form a false impression of society about the inhumanity, corruption, and bureaucracy of state machinery, thus working off the funds allocated by individual non-governmental organizations that pursue destructive goals in relation to the state structure of the Russian Federation. And another group such as opposition political forces often acts as "truth-tellers" who seek to earn votes of the electorate against the background of scandalous statements and "revelations".

Without conducting serious research and using even a superficial analysis of the information that is covered in the media on television, radio and the Internet, we can see for ourselves that the coverage of the work of correctional institutions is one-sided. In a wide media space, many reports about the work of the Federal Penitentiary Service of Russia and the administration of certain correctional institutions are presented in an extremely negative light. However, the mass media, unfortunately, are reluctant to inform the public about the great and socially significant and useful work that correctional institutions carry out not only in the field of reformation of convicts and preventing them from committing new crimes, but also in patriotic, veteran, sports, educational and other work. And it is in spite of the fact that such achievements are reflected in detail and almost on a daily basis on the official websites of institutions and bodies of the Federal Penitentiary Service of Russia on the Internet, as well as in departmental publications. However, such information about positive facts and examples from the life of employees of correctional facilities and their official activities is lost among the bulk of negative information that is widely presented in the media space.

Negative leaders from among the convicts are very sensitive to this kind of activity of such organizations and mass media and use them for their own criminal purposes to influence public opinion and use it as leverage in the process of investigating crimes and the work of the administration of a correctional institution.

Non-governmental and human rights organizations show a "false" interest in defending the rights and legitimate interests of convicts on the Internet. Artificially formed public opinion is aimed at justifying any illegal measures on the part of convicts who oppose the administration of a correctional institution (and this opposition is presented to general public as desperate measures that convicts have to undertake thus seeking to overcome "bureaucratism", "outrage" and "repressive measures", etc. of prison administration).

I.F. Gilyazov and V.N. Kudashov note that the opposition to the requirements of prison administrations on the part of convicts at the instigation of leaders of the criminal environment in recent years has been quite actively associated with the interference of "unscrupulous pseudodefenders and biased mass media in the work of correctional institutions" [2].

Such influence on the administration of a correctional institution can disorganize the work of the correctional institution, create conditions for mass riots, and facilitate the evasion of responsibility of persons from among the convicts who carry out illegal activities in the correctional institution.

A telling example is a riot in a correctional facility in the city of Angarsk, Irkutsk Oblast, on April 9-10, 2020, where a group of convicts disobeyed the legal requirements of employees of the Federal Penitentiary Service of Russia, inflicted injuries on themselves and took violent actions against a correctional institution employee. After that the convicts organized mass disruptions of prison order, numerous arson attacks on production facilities of the correctional institution, deliberate destruction of property, etc.

These events were accompanied by a surge in activity of various human rights organizations and charitable foundations, a flash mob in social media calling on human rights organizations, human rights defenders, activists and journalists to influence the investigation of the events in Correctional Facility number 15 of the city of Angarsk.

Russian Justice Minister K.A. Chuychenko, commenting on this situation, noted that "this riot was orchestrated from the outside, these same people paid for the so-called 'human rights defenders' who are still trying to stir up the situation in the mass media" [4].

We should point out that the successful counteraction provided by prison offenders is characterized by a very typical circumstance; they receive advice on providing such counteraction. They receive such consultations both from professional lawyers - defense lawyers 
$[5,8]$, and from other convicts (suspects and defendants) who, as a rule, have significant personal experience of participation in criminal proceedings and show analytical abilities to collect and understand other people's criminal experience. Moreover, the latter provide advice on countering criminal prosecution in certain situations even more professionally than lawyers by training [9].

\section{Conclusion}

Using a scientific approach that highlights the preliminary stage of the investigation of crimes, we have made an attempt to reveal the content and individual features of the counteraction provided by prison offenders. The methods of countering the investigation of penitentiary crimes, which are most often used directly by the perpetrators, include destruction, concealment, staging, and falsification. The indirect attitude of the perpetrators toward countering the investigation of penitentiary crimes is successfully implemented by creating a crowd effect, as well as using the mass media and the activities of human rights organizations.

\section{REFERENCES}

1. Bushinskaya M.G. Kriminal'noe protivodeistvie i puti ego preodoleniya pri rassledovanii moshennichestva: dis. ... kand. yurid. nauk. [Criminal counteraction and ways to overcome it in the investigation of fraud: Candidate of Sciences (Law) dissertation]. Moscow, 2006. 211 p.

2. Gilyazov I.F., Kudashov V.N. Prospects for the development of socio-psychological forms of work with convicted minors. Vedomosti ugolovno-ispolnitel'noi sistemy=Bulletin of the Penal System, 2013, no. 3, pp. 4-5. (In Russ.).

3. Ishchenko V.A. Protivodeistvie predvaritel'nomu rassledovaniyu v mestakh lisheniya svobody $i$ osnovnye napravleniya ego neitralizatsii: dis. ... kand. yurid. nauk [Counteraction to preliminary investigation in places of deprivation of liberty and the main directions of its neutralization: Candidate of Sciences (Law) dissertation]. Moscow, 2007. $176 \mathrm{p}$.

4. Kulikov V.S. Head of the Ministry of Justice: The revolt in the Angarsk colony was orchestrated from the outside (Code of health). Rossiiskaya gazeta=Russian Newspaper, 2020, April 15, no. 81. (In Russ.).

5. Malyshkin P.V. Concept and essence of counteraction to the investigation of crimes by a defense lawyer. Mir nauki $i$ obrazovaniya=World of Science and Education, 2015, no. 4, pp. 14-27. (In Russ.).

6. Morozov R.M., Ostapenko V.N. Features of overcoming the counteraction carried out by suspects (accused) at the initial stage of investigation of remote fraud committed in penitentiary institutions. Penitentsiarnaya nauka=Penitentiary Science, 2019, vol. 13, no. 4, pp. 543-551. (In Russ.).

7. Nikolaichenko V. V. Penitentsiarnye i postpenitentsiarnye prestupleniya : kriminalisticheskaya teoriya i praktika: dis. ... $d$-ra. yurid. nauk [Penitentiary and post-penitentiary crimes: criminalistic theory and practice: Doctor of Sciences (Law) dissertation]. Saratov, 2006. Pp. 350-356.

8. Pavlov A.A. Forms of counteraction to the investigation of crimes by the defender. Aktual'nye problemy teorii $i$ praktiki ugolovnogo sudoproizvodstva $i$ kriminalistiki=Topical Issues of the Theory and Practice of Criminal Justice and Criminalistics, 2004, pp. 173-183. (In Russ.).

9. Polikarpov B.A. Protivodeistvie ugolovnomu presledovaniyu v sledstvennykh izolyatorakh i kriminalisticheskie sredstva ego preodoleniya: dis. ... kand. yurid. nauk [Counteraction to criminal prosecution in pre-trial detention centers and criminalistic means for its overcoming: Candidate of Sciences (Law) dissertation]. Ulan-Ude, 2017. 292 p.

10. Spiridonova Yu.N. On certain issues of legal regulation of the criminal procedure status of officials of the Federal Penitentiary Service. Vestnik instituta: prestuplenie, nakazanie, ispravlenie=Bulletin of the Institute: Crime, Punishment, Correction, 2017, no. 4, pp. 34-38. (In Russ.).

11. Shurukhnov N.G. Influence of criminal procedure legislation on the structure of crime investigation. In: Ugolovnoe sudoproizvodstvo: problemy teorii, normotvorchestva i pravoprimeneniya: sb.nauch.tr. [Criminal proceedings: problems of theory, norm-making and law enforcement: Collection of scientific works]. Ryazan: Akademiya FSIN Rossii, 2007. Issue 2. Pp. 147-156. (In Russ.).

12. Shurukhnov N.G. Factors affecting the investigation of crimes committed by convicts in correctional labor institutions. In: Aktual'nye voprosy ispol'zovaniya dostizhenii nauki i tekhniki v rassledovanii prestuplenii organami vnutrennikh del [Actual issues of using the achievements of science and technology in the investigation of crimes by internal affairs bodies]. Moscow, 1990. Pp. 101-107. (In Russ.).

\section{INFORMATION ABOUT THE AUTHOR}

ALEKSANDR V. AKCHURIN - Candidate of Sciences (Law), Associate Professor, Head of the Department of Criminal Procedure and Criminalistics, Academy of FSIN Russia, Ryazan, Russian Federation. ORCID: https://orcid.org/00000003-1742-1162, e-mail: 79206310258@yandex.ru 